\title{
Quantifying and Accounting for Environmental Costs by the Avoidance Cost's Method: The Case of a Tunisian Firm
}

\author{
Amara Tijani ${ }^{1}$ and Fakhfakh Hamadi ${ }^{2}$ \\ ${ }^{1}$ Comptabilité Institut Supérieur d'Administration des Entreprises, Université de Gafsa, Tunisie \\ ${ }^{2}$ Finance Faculté des Sciences Economiques et de Gestion, Université de Sfax, Tunisie
}

Received 27 June 2012; Accepted 26 September 2012; Published 26 January 2013

Academic Editor: Mariana Gurau

\begin{abstract}
Working under a view of social ethics, implies that the firms must behave like a responsible citizen. This entails rights as obligations to the community. In this perspective, the company is now responsible for negative consequences produced by its activities. The company well knows, to minimize risk by controlling the environmental costs incurred by society. Although these costs represent a threat to some companies for performance, others consider them a competitive factor.

Throughout this work, we will demonstrate, through a case study, the environmental costs, despite the ambiguities related to calculation, can be identified and recorded in the financial reports of the company. To do this, the researchers will proceed as follows. A first section will present the theoretical framework of this research by discussing the concepts of environmental costs. The second section will be reserving for environmental costs. In the last section, the researchers present calculations of the various environmental costs and bookings in the financial reports of the company.
\end{abstract}

Keywords: Environmental costs, Accounting, Performance, Environmental protection.

\section{Introduction}

The consumption at an excessive rate of resources and the preservations of nonrenewable resources and pollution of air and water are mainly recognizing as the three threats today. Therefore, it appears a significant change in the social interest. Thus, the public opinion is trying to regain his power of reflection and criticism. In this context, the researchers talk more and more about a universal citizenship based on a participatory approach. This is as shown in Sachs (1987) a "synchronic solidarity with the present generation, a diachronic solidarity with future generations and an ethics based on universal citizenship." The outcome of this situation involves, in addition to economic growth, a green movement at the top of the completely social body, that is to say, mental and social changes of the whole society, which is likely to increase cumulatively and sustained real global product of society (including the environmental dimension). For businesses, create wealth in the nation, they are challenged to meet their needs not only

Copyright (C) 2013 Amara Tijani and Fakhfakh Hamadi. This is an open access article distributed under the Creative Commons Attribution License unported 3.0, which permits unrestricted use, distribution, and reproduction in any medium, provided that original work is properly cited. Contact author: Amara Tijani E-mail: tijani_amara@yahoo.fr 
economic but also social needs by participating in building a rewarding social ethics

Undertaken with a view of social ethics, implies that the company must behave first like a responsible citizen because it does not operate in a sociological vacuum. This entails rights but also duties. Gradually, companies direct their concerns towards minimizing the negative effects of their products on the environment. This is possible by mastering the environmental costs generated by their activities and supported by the community. Although these measures companies are not yet widespread among all companies, Andrew (1999) confirms that the majority of them consider that environmental protection is a competitive factor.

Aware of the challenge of the world's ecological capacity, implying that we cannot think of the economy without considering its environmental impacts, and conversely it is impossible to envisage society regardless of economic practices. Based on this viewpoint, the Phosphates company of Gafsa was the first (on the national stage) to become conscious of the challenges of environment and ecological issues.

Among the first lessons, we have learned by studying the fundamentals of the economy, is the principle of arbitration in decision making, regardless of individual or collective. The choices of modern arbitration, imposed by the problem of shortages, oppose clean environment and income level (high costs for businesses). In this view, laws against pollution force the companies to reduce pollution levels result in higher production costs of goods and services. Thus, the environmental protection has been long considering as an obstacle for companies. According to Martel et al (1997) companies still worries about their financial situation. The companies hesitate for adopting environmental policies under the pretext that they are generating loads unrecoverable.
In this paper, we will demonstrate through a study case that the environmental costs, despite the ambiguities related to calculation, can be identifying and integrating in the financial reports of the company. To do this, the researchers will proceed as follows. The first section will present the theoretical framework of this research by discussing the concepts of environmental costs. The second section will be reserving for environmental costs. In the last section, the researchers will present the calculations of the various environmental costs and bookings in the financial reports of the company.

\section{The Theoretical Framework of the Research}

As part of this work, we use the concepts of environmental costs generated by the activities of companies and supported by the community. These costs are known as negative externalities for which there is no market. In this section, the researchers will present first, the definition of the environmental costs. The ambiguities associated with the calculation of environmental costs will be discussing in the second section. Finally, the researchers will discuss the methods for calculating these costs.

\section{Definitions of Environmental Costs}

The definition provides that a company environmental cost generally depend on how it expects to use the information gathered. It is very difficult to know, what an environmental cost is consider. This is also not essential; the important thing is rather to ensure that the relevant costs receive attention. In a document entitled "Environmental Cost Primer", the U.S. Agency for Environmental Protection (2001) offers a framework for determining environmental costs, which are classifying into the following broad categories:

- Traditional Costs corporate: They are defining as costs that are generally accepted in the analysis and evaluation of investments, such as capital and raw materials. 
- Sometimes hidden costs: They result from activities undertaken to comply with environmental legislation or exceed legislative requirements.

- Potential Costs: These are costs that the company may need to take and which are of questionable character, as the cost of remediation works it has to pay or benefits payable in the event of environmental accidents.

- Costs related to branding and public relations: They correspond to the expenditures to influence the subjective perception that stakeholders have from the company, such as costs of preparing the annual environmental report.

- Costs for involuntary breaches: As the fines imposed under environmental laws, they are borne directly by the company and considered as internal costs.

- External environmental costs: They are related to the damage of the environment. They include certain contingent liabilities, as the risk of having to decontaminate a site or having to pay compensation for damage to natural resources (bodily injury and property damage).

\section{The Analysis of Environmental Costs}

The hierarchical analysis of costs allows the company to determine the tools and techniques that can help identifying the activities, processing and producing that result in environmental costs.

When the inventory and cost allocation criteria do not allow a fair evaluation of all investments, companies do not always have the information needed to make optimal use of limited resources, particularly for projects environmental focus on pollution prevention.

To solve this problem, the U.S. Agency for Environmental Protection (EPA) has developed a method of hierarchical analysis of costs helping to identify the environmental costs. This method of prevention of pollution class costs into four levels:

- Level 0 the usual costs;

- Level 1 Hidden Cost;

- Level 2 Environmental liabilities;

- Level 3 tangible less costs.

The hierarchical analysis of costs, according to Martel et al. (1997), helps the company to consider the full range of environmental costs. She favors a better quantitative analysis. Companies can first analyze the cost of level 1 . If this analysis reveals no economic advantage, they may wish to consider the cost of level 2 , and so on. By analyzing its projects to prevent pollution, the company is not obliged to assess all levels of costs to demonstrate the reliability of each of its economic projects.

\section{The Environmental Costs: Ambiguities and Computational Constraints}

While it is important to integrate environmental issues in business economics, Aboud (1990) points out several problems:

- The technical problems associated with pollutant measurements: measurements of pollutants are generally subjective. To avoid conflicts with the community, it is desirable that state intervention and control strictly the limits prescribed by the standards;

- The passage of the principle of "the company pays" principle of "polluter pays" has caused many problems for companies. The latter view it as an exhausted their own resources.

In return, the victims affected by pollution will not accept to be the only ones that bear directly or indirectly the consequences;

- The environmental costs may delay the development of investment and this negatively affects employment opportunities; 
- Some companies do not meet environmental standards. Consequently, they do not incorporate environmental costs in calculating the cost of its products. Other firms that internalize environmental costs cannot set a competitive retail price and risk as well losing their market share.

Regardless of these problems, the evolution of social awareness towards environmental issues, require accurate calculations of costs.

Currently, there are methods such as technique hedonic to measure the costs and current and future opportunities related to the environment. In this context, Belhadj (2003) notes that the choice between these methods depends on the following:

- Among the objects of cost accounting aims to achieve, we find the identification of sources of pollution. This objective can rationally allocate the costs of pollution to responsibility center;

- Generally, the polluter is not solely responsible for environmental damage. The company, even if it is clean, with the objective of achieving national economic benefits. Several sectors such as agriculture will benefit from its products for the production of other necessary goods (agricultural products). Therefore, the responsibility towards the environment is common;

- Intervention by environmental standards is an effective component for environmental protection;

- The estimated volume of environmental costs is affected by the nature of citizens around the source of pollution. Sometimes people are sensitive, sometimes the damage is very high. It is better to invest in this case the maximum possible for the protection of the environment;

- Among the objectives of the measurement and control of pollution, there is damage prevention there under (health and material). These negative externalities could be controlled before and after pollution. On this basis, companies are required to conduct studies on the impact of their activities on the environment before starting.

To take into account the costs and benefits of business affect on the environment, we must be able to measure externalities. In this context, Milne (1991) confirms that one of the problems we may face when it comes to incorporate environmental costs and benefits to the financial statements is the measurement problem. Several researchers support this proposal. Pearce et al. (1989) indicate that externalities are often intangible and there is no market in which they are traded.

However, economists have developed different techniques to obtain nonmonetary value of resources traded in markets. Thus, consideration of externalities and their internalization in the financial statements of companies may increase significantly, especially for accountants, the level of uncertainty and therefore risk associated with their work. For Fortin (1995), this situation leaves much margin for judgment in the audit work. It turned out well; the methods for estimating environmental costs have not made the final agreement among economists that, by applying their calculations, are in the presence of varying estimates of costs resulting from a same project or a single policy. Major sources of uncertainties in estimating costs, are often cited the changing technology and changing preferences.

\section{Environmental Costs: Calculation Methods}

Research on evaluation of environmental costs offer a variety of methods that poses the problem of objectivity and reliability of those methods (Vergnaud, 2001). As for the assessment, tools themselves differ and provide different results. We present in this section, the methods for assessing environmental costs witch is the best known and frequently used while detailing the proposed method for the evaluation of 
externalities, regarding this research, namely the method of cost avoidance.

* The method of cost avoidance: According to Dreveton et al. (2003), this method requires to design a new mechanism to identify the environmental impact of company activities. The concept of environmental impact is defined as the set of factors that disrupt the environment. The objective is therefore to evaluate in monetary stress points between the actions of the company and their environmental consequences. Two categories of actions seem to initiate the interaction of the company with its environment. Initially, the company may seek to avoid any environmental nuisance (preventive actions) and a second time, she tries to repair the environmental damage caused by its activities (remedial actions). For each measures, Benjamin et al. (2007) report that will match a specific cost: the cost avoidance (prevention) or the cost of maintenance (repair).

The cost method of avoidance is generally assumed that the damage affecting society, depend entirely on abatement costs. Rinaudo et al. (2005) notes that new technologies adopted, will minimize the amount of pollutants emitted, and therefore, reduce the damage caused by pollution. Thus, we can say that the company works to a clean environment and conserves the natural resources.

* The method of restoration: This method forces the polluting company to reduce the negative effects of its activities. For this purpose, it must bear the costs of restoration.

* The contingent valuation method: It measures individual variation in welfare associated with a change in the situation of individuals exposed to air pollution. It involves asking random value that people attach to an environmental service by asking them what they would be willing to pay or receive to preserve or to tolerate an environmental good. It may be a willingness to pay (WTP) to benefit from an improvement (or to avoid a deterioration) of air quality for example, or a willingness to accept (WTA) the degradation or to refuse an improvement. This information allows, according to Willinger et al. (1996), to construct indicators of monetary value that agents assign to different components of their health, or any property with no money. This method assumes that agents act in an economically rational and properly include all components of the proposed scenario. Its results are sensitive to the subjective perception of risk and the ability of processing the information provided. Moreover, this approach assumes, as indicated Luchini (2004), that individuals are able to assess their own damage functions. Finally, this method could be affected by the answers of respondents, who may seek to influence the outcome by minimizing the willingness to pay and maximizing consent to receive.

* The cost method of damage: This method traces the progress of pollutants from where they issued until the final impact by following a logicall series of steps:

- Identification of hazards of pollutants;

- Establishing links between hazards and pollutants;

- Quantitative estimation of impacts related to pollutants;

- Monetization of impacts related to pollutants.

\section{Environmental Costs: The Case of the Company of Phosphates of Gafsa}

Integrating the environmental dimension in the company's strategy involves taking into account at all levels. In this sense, Caroline (2005) argues that the determination of environmental costs generated by the activity of the company, and related financial information, account, including stakeholders, tools for performance evaluation of company and therefore making decisions. In this context and in response to requirements for 
environmental performance, the Company of Phosphates of Gafsa (CPG) has adopted a set of principles designed to improve its practices in production and marketing of its products. Under this section, we will present first, the field of research of this study and a description of its production process and the impacts of its activities on the environment. Then we will present the details of the costing of environmental degradation by the method of cost avoidance.

\section{Brief of the Company of Phosphate of Gafsa}

With a century of experience in operating and marketing of Tunisian phosphates, the CPG is one of the largest phosphate producers in the world. She ranks fifth worldwide in 2010.

The CPG operates ten quarries spread over five mining centers. At the geological scale, all producing fields back to the Eocene. The surface mining of phosphates Tunisia has made significant gains in cost of production, which has improved productivity. The CPG currently operates seven open pits and one underground mine. Annual production in 2010 reached 8 million tons of phosphates.

About $80 \%$ of domestic production of phosphate is delivering to local processing plants of Tunisian Chemical Group. Gafsa phosphate is marketing in over twenty countries around the world both for processing as for direct application.

\section{The Costs of Environmental Degradation}

It is important to note that the calculation of environmental damage by the method of cost avoidance is associated with many uncertainties for several reasons including:

- Environmental problems according to Belhadj (2003) cannot be dividing into distinct categories (water, air, soil ...).
They are often linked which makes direct comparison between the cost of damage and replacement cost rather complex;

- Avoidance costs are overstated and in some cases exceed the funds needed to prevent environmental damage. Despite these shortcomings, our study will take into consideration the cost avoidance method. In fact, the application of other methods of assessing environmental damage is actually associated with several shortcomings such as lack of information in polluting industries.

The CPG has launched a project witch aims to reduce the harmful effects of mining and production of phosphates on the environment. This helps to:

- Controlling the impact of mining on the natural environment;

- Implementing safe operating conditions for staff;

- Protecting agricultural land;

The draft Waste Management for laundries of the CPG is an important initiative to improve the quality of the environment. This project allows, also, the strengthening of the national management of water resources and a solution of water production in place of water wells.

Storage of fine tailings in containment sumps can, indeed, the use of a new water source by the unconventional GC (recovery and recycling of industrial water from sludge clay). It also reduces, land degradation and protect agricultural land, plants and quality of life of animals.

The total cost at completion was about 16.000.000 Tunisian dinars. The firm paid all costs. The details of costs by sector are as follows: 
Table (01) Total Cost

\begin{tabular}{|l|c|}
\hline Sectors & Cost (DT) \\
\hline Sector 1 & 3.725 .000 \\
\hline Sector 2 & 2.285 .000 \\
\hline Sector 3 & 6.000 .000 \\
\hline Sector 4 & 4.000 .000 \\
\hline Total & 16.000 .000 \\
\hline
\end{tabular}

The means of protection used by the firm tackle environmental damage, helping to:

- Avoiding the level of pollution at its source;

- Improving the quality of the environment;

- Preserving in particular water resources.

\section{Accounting for Environmental Costs}

According to Brulotte (1995), the accounting system has become the nervous system of each company. It enables analysis, processing and transmitting information of all kinds. However, this system is characterizing according to Beechey et al (1987) by the absence of a solution for integrating environmental issues in corporate financial reporting given the shortcomings associated with the valuation of environmental costs. However, the growing concerns of the stakeholders are given a high priority to a new accounting system that integrates and discloses environmental information in financial reports of the company.

In response to these needs, Shaltegger et al (2000) reported that Fleischmann and Paudke (1977) have introduced a step to separate the calculation of the costs and benefits related to the implementation of anti-pollution measures. In the same context, the book Memento (2005) states environmental expenditures are those made to preventing, reducing or repairing the damage caused by company activities. For our case study, we opt for the method of activity-based costs. This method allows both the efficient allocation of costs and the identification of creative activities for environmental costs.

\section{Treatment of Environmental Costs by the ABC Method}

Currently, the firm applies the method of full costs for the calculation of cost prices of its products. This method integrates all charges reported based on the internal organization of the company. The full cost includes all costs (direct and indirect) as well-defined keys. However, this method does not provide information tailored to specific needs related to environmental issues. This inefficient allocation of costs actually complicates the process of decision-making.

Based on these principles, we opt for the method of calculating costs based on activities for the analysis and the allocation of costs of various activities of the firm.

The processing and analyzing costs by the $\mathrm{ABC}$ method requires the definition of activities within the company, the identification of reference, which will be subject to treatment, the establishment of links between these charges, and activities and finally, the links between activities and products manufactured.

\section{Identification of Activities in the CPG}

The activities of the CPG are classifying in principal activities and secondary activities.

The main activities are the heart of the company's business. They are essentially the extraction, production and marketing of phosphates.

At each main focus of secondary activities such as business administration, procurement and maintenance. The set of directions, which represents the subactivities, is secondary activities. The following table summarizes the various activities in the CPG. 
Table (02) Identification of Activities in the Firm

\begin{tabular}{|c|c|c|}
\hline Main activities & Secondary activities & sub-activities \\
\hline \multirow[t]{6}{*}{ Extraction } & \multirow{6}{*}{ Administrative } & Administrative direction \\
\hline & & Financial direction \\
\hline & & Management training \\
\hline & & Social leadership \\
\hline & & Général direction \\
\hline & & Management control \\
\hline \multirow{11}{*}{ Production } & Procurement & Inventory management Branch \\
\hline & \multirow{5}{*}{ Washing and Drying } & Research and development branch \\
\hline & & Sector 1 \\
\hline & & Sector 2 \\
\hline & & Sector 3 \\
\hline & & Sector 4 \\
\hline & \multirow[t]{4}{*}{ Protection of the environment } & Sector 1 \\
\hline & & Sector 2 \\
\hline & & Sector 3 \\
\hline & & Sector 4 \\
\hline & Maintenance & Direction of matériel maintenance \\
\hline Commercialisation & Commercial & Commercial général direction \\
\hline
\end{tabular}

Source : Researcher Works

To facilitate the integration of environmental damage in the analytical reports of the CPG, we added secondary activities witch we named "Environmental Protection". This activity is secondary to the principal activity "Production". It includes laundries of different sectors that are major causes of environmental damage. We find it very useful to identify other activities to facilitate the efficient allocation of costs. In addition, we are particularly interested in the treatment of environmental loads at the secondary activity "Environmental Protection".

\section{Identification of Cost Drivers}

The cost driver is the indicator of business volume. This is to investigating the factors that best explain the consumption of resources. The cost driver reflects a causal relationship between consumption of the CPG resources and the activities. The analysis of the various activities of the CPG highlights the following cost drivers:

Table (03) Cost Drivers

\begin{tabular}{|l|l|}
\hline Activities & Cost drivers \\
\hline Administrative & Employees \\
\hline Procurement & Consumable material \\
\hline Washing and Drying & Tonnage mined and implemented \\
\hline Protection of the environment & Tones discharges \\
\hline Maintenance & Accumulated depreciation \\
\hline Commercial & tones sold \\
\hline
\end{tabular}

Source: Researcher Works

\section{Identification of Environmental Loads}

The identification of environmental loads requires prior separation of expenditures that have a kind of investment from those who have a kind of current expenses. For the case of the CPG, all expenses related to environmental protection are about 16 million TD. However, processing and analyzing of these costs reveals the following remarks:

Among the charges involved, we find those to be charge to the cost of 
production of phosphates such as depreciation, personnel costs, spare parts, workshops and liquid fuels. However, these loads should be distinguishing as environmental loads in the notes to the income statement and notes to financial statements.

Other expenses such, as investment in equipment should be capitalizing because they relate to purchases of durable equipment. According to the Tunisian Accounting Standard No. 5, an asset is included in the balance sheet when it has the potential to generate future benefits. In the same direction, IAS 07.16 states that the cost of an asset is capitalizing when it is probable that future economic benefits associated with the item will flow to the company. On this basis, the Environmental expenditures that relate to a tangible asset, therefore derogate from this principle.

They are recognizing as assets for the economic benefits they present to the future.

The following table provides a classification of environmental costs incurred by the CPG classified according to the nature of imputation:

Table (04) Allocation of Environmental Loads

\begin{tabular}{|l|l|l|}
\hline Environmental loads & Nature of imputation & Allocation \\
\hline Personnel expenses & Current expenses & Income statement \\
\hline Liquid fuels & Current expenses & Income statement \\
\hline Investment in material & capitalized & Balance sheet \\
\hline Works workshops (maintenance) & Current expenses & Income statement \\
\hline Current expenses spares & Current expenses & Income statement \\
\hline Depreciation & Current expenses & Income statement \\
\hline
\end{tabular}

Source : Researcher Works

\section{Analytical Calculation of Environmental Costs by Industry}

Creating a secondary activity, "Environmental protection" that we proposed, we are committed to identifying environmental loads in the four sectors that have been installed storage tanks for releases laundries. The majority of these charges, with the exception of the acquisition cost of durable equipment, will be charging as common environmental loads. The following table presents details of expenses in each sector: 
Table (05) Environmental Loads in Each Sector (Tunisian Dinars)

\begin{tabular}{|c|c|c|c|c|c|}
\hline \multirow{29}{*}{ 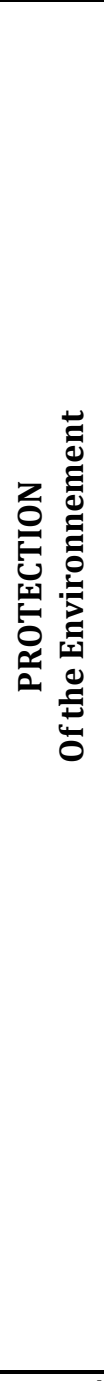 } & \multirow{7}{*}{ SECTOR 1} & Environmental loads & 2009 & 2010 & 2011 \\
\hline & & Personnel expenses & 59394 & 173039 & 99595 \\
\hline & & Liquid fuels & 15434 & 184236 & 70049 \\
\hline & & Works workshops & 109166 & 99078 & 71833 \\
\hline & & Current expenses spares & 12241 & 203320 & 72348 \\
\hline & & Depreciation & 38182 & 115771 & 38181 \\
\hline & & Total & 234417 & 775444 & 352006 \\
\hline & & Environmental loads & 2009 & 2010 & 2011 \\
\hline & & Personnel expenses & 56566 & 164805 & 94852 \\
\hline & & Liquid fuels & 14699 & 175463 & 66714 \\
\hline & & Works workshops & 103968 & 94360 & 68412 \\
\hline & & Current expenses spares & 13563 & 193647 & 68903 \\
\hline & SECTOR 2 & Depreciation & 36364 & 110258 & 36364 \\
\hline & & Total & 225160 & 738533 & 335245 \\
\hline & & & & & \\
\hline & & Environmental loads & 2009 & 2010 & 2011 \\
\hline & & Personnel expenses & 76364 & 222487 & 128050 \\
\hline & & Liquid fuels & 19843 & 236875 & 90063 \\
\hline & & Works workshops & 140357 & 127386 & 92356 \\
\hline & SECTOR 3 & Current expenses spares & 18310 & 261423 & 93019 \\
\hline & & Depreciation & 49091 & 148849 & 49091 \\
\hline & & Total & 303965 & 997020 & 452579 \\
\hline & & Environmental loads & 2009 & 2010 & 2011 \\
\hline & & Personnel expenses & 87677 & 255448 & 147020 \\
\hline & SECTOR 4 & Liquid fuels & 23883 & 271968 & 103406 \\
\hline & & Works workshops & 161650 & 146258 & 106040 \\
\hline & & Current expenses spares & 21421 & 300167 & 106800 \\
\hline & & Depreciation & 56364 & 170900 & 56364 \\
\hline & & Total & 350995 & 1144741 & 519630 \\
\hline
\end{tabular}

Source: Researcher Works based on the financial reports of the firm

\section{Discussion}

Based on the data provided on the environmental loads by sector, we can run the following remarks:

The administrative division of expenses is dependent on the source of environmental impact. In this perspective, we identified 10 phosphates laundries located in the four sectors.

Given that the CPG uses the full cost method for calculating the cost of its product, we performed the separation of charges relating to the protection of the environment of those on ordinary activities of the CPG.

In 2008, the CPG predict to increase the capacity of sewage waters in most areas to recover the maximum possible industrial water. This has indeed increased the total charges and particularly those of depreciation.

The launch of storage basins contributed to the creation of new job positions, especially in 2008.

- The distribution of environmental burdens between sectors is doing according to the drivers that match the nature of expenses. 
- Areas of Sector 3 and Sector 4 consume more expenses than the other sectors. This is justified, indeed, by the number of existing laundries in these two sectors (6 laundries).

- The life of each storage discharges for laundries is 5 years. The companies renewing the ancient storage or install some new ones.

\section{Allocation Recognition of Environmental Expenditure}

Environmental expenditures are recording fewer than two headings:

- Environmental expenditures recorded as current expenses such as staff costs, depreciation and consumables.

- The environmental expenditure capitalized as assets of the company it is likely that these expenses will have the ability to generate future benefits such as investment purchases. For our case, the expenses incurred by the CPG to protect the environment are of two types. Staff costs, heating oil, the work of workshops, spare parts and depreciation will be charging to the income statement as investment purchases will be entering in the assets of the company and will be submitting to the straight line.

\section{Allocation of Environmental Expenditures as Current Expenses}

In reference to the Tunisian accounting, all environmental expenditures recorded as current expenses should be charged in $6^{\text {th }}$ class. However, it is important to distinguish between ordinary load and that related to environmental protection. For our case, we propose adding a new classification to $6^{\text {th }}$ class in order to distinguish them from the other ordinary expenses. The following table summarizes the allocation of environmental loads such as we propose:

Table (06) Allocation of Environnemental Loads

\begin{tabular}{|l|l|l|}
\hline Environmental loads & Account to be charged & Nomenclature proposed \\
\hline Personnel expenses & 64. Personnel expenses & $\begin{array}{l}\mathbf{6 4 1} \text {. Personnel expenses related to } \\
\text { the Environment protection }\end{array}$ \\
\hline Liquid fuels & $\begin{array}{l}\mathbf{6 0 2 .} \text { Stored purchases - } \\
\text { Other supplies }\end{array}$ & $\begin{array}{l}\mathbf{6 0 2 7} \text { Environmental consumable } \\
\text { materials and supplies }\end{array}$ \\
\hline Works workshops & $\begin{array}{l}\text { 615. Maintenance and } \\
\text { repairs }\end{array}$ & $\begin{array}{l}\mathbf{6 1 5 1} \text { Maintenance and repairs of the } \\
\text { Environment protection }\end{array}$ \\
\hline $\begin{array}{l}\text { Current expenses } \\
\text { spares }\end{array}$ & $\begin{array}{l}\mathbf{6 0 2} \text {. Stored purchases - } \\
\text { Other supplies }\end{array}$ & $\begin{array}{l}\mathbf{6 0 2 7} \text { Environmental consumable } \\
\text { materials and supplies }\end{array}$ \\
\hline & $\begin{array}{l}\mathbf{6 8 1} \text {. Dépréciations and } \\
\text { supplies }\end{array}$ & $\begin{array}{l}\mathbf{6 8 1 1 2 1} \text { Environmental tangible } \\
\text { assets }\end{array}$ \\
\hline
\end{tabular}

Source: Researcher Works based on the Tunisian Accounting system

\section{Capitalization of Environmental Expenditure}

According to the sixth paragraph of the Tunisian Accounting Standard $n^{\circ} 5$, the asset is the one having a physical and tangible potential to generate future benefits to the company. This definition corresponds in fact to the amounts incurred by the CPG in the form of investment for environmental protection. The study witch we conducted showed us that these investments have contributing to preventing and reducing of future damages and generating profits for the company. Thus, it is advisable to include in the balance sheet under "Fixed assets". However, for reasons of transparency, it is important to distinguish the environmental assets from the other ordinary. This will serve stakeholders in efforts provided by the CPG for environmental protection.

In this context, we propose that investments engaged by the CPG will be listed under the heading 22 "Fixed assets" and in particular in the account 228 "Other tangible assets" that are proposed to add a 
sub account 2283 "General facilities and developments related to environmental protection." At the end of each financial year, these facilities shall be subject to straight-line depreciation based on the life of the depreciable property. The proposals for accounting of environmental issues in the financial reports of the CPG, affect the balance sheet and the income statement. Therefore, the proposed accounting changes the financial situation of the CPG. In this context, Moroncini (1998) suggests that it is important that the financial implications of environmental consideration are properly identifying, evaluated and recorded. The following table shows the various accounting changes in the balance sheet in reference of the Tunisian Accounting system:

Table (07) Model of the Balance Sheet

\begin{tabular}{|l|l|}
\hline \multicolumn{1}{|c|}{ ASSETS } & \multicolumn{1}{c|}{ LIABILITIES } \\
\hline $\begin{array}{l}\text { Non-current Assets } \\
\text { 21. Non - tangible Assets. }\end{array}$ & Owners Equity \\
22. Tangible Assets. & Non-current liabilities \\
$\begin{array}{l}\text { 2283. General facilities and developments } \\
\text { related to the environmental protection }\end{array}$ & 16. Borrowings \\
$\begin{array}{l}\text { 26. Others Financial Assets. } \\
\begin{array}{l}\text { 27. Others non curent Assets. } \\
\text { 28. Accumulated Dépréciation. }\end{array}\end{array}$ & 18. Other financial liabilities \\
\hline
\end{tabular}

For the income statement, it is important to distinguish between loads and environmental products other current items. The change affects all non-current assets. The other balance sheet item that will be affected by those changes depends of regulation: a decrease in the bank account if the payment of purchases of investment is funding in cash or an increase in naval loans if the debt is settled banking.

We propose that the costs and environmental products will be exempting from tax in order to encourage companies to take action for environmental protection. The following table shows the various accounting changes in the income statement in reference

Table (08) Model of Income Statement

\begin{tabular}{|c|c|}
\hline I & $\begin{array}{l}\text { Cost of sales } \\
\text { Operating Income }\end{array}$ \\
\hline & $\begin{array}{c}\text { Financial Products } \\
\text { Other gains ordinary }\end{array}$ \\
\hline II & Financial Results \\
\hline I+II & Income for the year \\
\hline \multicolumn{2}{|r|}{ (Income tax) } \\
\hline \multicolumn{2}{|r|}{ Profit on ordinary activities after tax } \\
\hline \multicolumn{2}{|r|}{$\begin{array}{c}\text { Environmental expenses } \\
\text { Results of environmental activities }\end{array}$} \\
\hline \multicolumn{2}{|r|}{ Extraordinary items (gain / loss) } \\
\hline \multicolumn{2}{|r|}{ NET INCOME FOR THE YEAR } \\
\hline \multicolumn{2}{|r|}{ Effect of accounting changes (net of tax) } \\
\hline \multicolumn{2}{|r|}{ Net Income after accounting changes } \\
\hline
\end{tabular}




\section{Conclusion}

The company of phosphate of Tunisia, through the expenses incurred to mitigate the environmental consequences of its activities, has become responsible vis-à-vis to the community and to the future generations. These expenses are, in fact, the cost of avoiding the probable degradation of the environment. Despite the limitations that characterize the application of the method of cost avoidance, it remains, for our case study, the most relevant information provided to decision makers and users of financial reports of the company.

In this study, we demonstrated also that taking into consideration the environmental issues in production costs allows the company, on the one hand, rationalizing its consumption of natural resources in substantial savings and on the other hand, answering the demands of society in improving the quality of the environment. By adopting the method of activity-based costs, we identified the sectors involved in environmental pollution. This allowed the company to create an additional activity "Environmental Protection" in addition to other regular activities. This new activity will, in fact be created, not only at the main activity "Production" but also, at the first major activity "Extraction" which, in turn, has negative consequences on the environment represented by air pollution.

Quantification of environmental costs should be accompanying by the integration of those costs with particular care in the financial statements. However, the absence of separate accounts and accounting standards regarding the environment makes it difficult to cash charge for these costs. With reference the Tunisian accounting system, we have proposed many solutions to address this deficiency. The demonstration conducted under this study is debatable especially in the proposed classifications.

\section{References}

Aboud, N. (1990). 'Evaluation Economique des Programmes de Protection de L'environnement,' Revue d'Economie, Baghdâd Press.

Andre, P. (1999). 'L'évaluation des Impacts sur L'environnement - Processus Acteurs et Pratiques,' Canada: Presses Internationales Polytechniques, $\mathrm{p} 416$.

Beechy, T. H. (1987). "Comptabilité Financière Avancée," Montréal Editions, Etudes Vivantes.

Belhaj, M. (2003). "Estimating the Benefits of Clean Air Contingent Valuation and Hedonic Price Method," Journal of Global Environment.

Brulotte, R. (1995). "Environnement, Economie et Entreprise," Sainte-Foy, Télé Université, Collection Sciences de l'environnement, ISBN 2-7624-0839-3, 547 p.

Burritt, R. L., Hahn, T. \& Schaltegger, S. (2002). "Towards a Comprehensive Framework for Environmental Management Accounting - Links between Business Actors and Environmental Management Accounting Tools," Australian Accounting Review, 12(2): 39-50.

Chanel, O., Vergnaud, J. C. \& EUREQua, G. (2001). "Monétarisation des Effets de la Pollution Atmosphérique: Un Etat de L'art Pluridisciplinaire," Rapport Greqam, Eurequa pour le Compte de la DRAST et du PREDIT.

Dreveton, B. (2006). 'Les Enjeux du Processus de Construction d'un Outil de Contrôle de Gestion des Activités Environnementales: Le Cas des Collectivités Locales,' Gestion 2000.

Farley, L., Gauthier, Y., Leblanc, M. \& Martel, L. (1997). 'Guide D'introduction à la Comptabilité Environnementale,' Environnement Canada et Ordre des Comptables agréés du Québec. 
Fortin, J., Martel, L. \& Rakotosoa, E. (1995). "Enjeux Comptables de la Question Environnementale," Accounting Ethics Journal. Montréal, Quebec, H3T 1 V6.

Gallez, C. \& Moroncini, A. (2003). "Le Manager et L'environnement: Outils D'aide à la Décision Stratégique et Opérationnelle," Presse Universitaire Romande Lausanne.

Luchini, S., Paraponaris, A., Protière, C. \& Vergnaud, J.- C. (2004). "Les Consentements à Payer Pour des Programmes de Prévention Sanitaire Incluent-ils de L'altruisme? Enseignements d'une Enquête Concernant la Fièvre Q," Revue Economique.

Markandya, A. \& Pearce, D. (1989). 'L'évaluation Monétaire des Avantages des Politiques de L'environnement,' Paris, $O C D E$.

Milne, M. J. (1991). "Accounting Environmental Resource Value, and NonMarket Valuation Techniques for Environmental Resources: A review," Accounting Auditing \& Accountability Journal, vol.4, $\mathrm{n}^{\circ} 3$.

Pierre, B. \& Benjamin, A. (2007). "L'évaluation des Impacts Environnementaux: Une Grille de Lecture," sur http://www.management.free.fr/recherch e/contenucongres/AFC/p106.pdf.
Pretty, J., Brett, C., Gee, D., Hine, R., Mason, C., Morison, J., Rayment, M., Van der Bijl, G. \& Dobbs, T. (2001). "Policy and Practice; Policy Challenges and Priorities for Internalizing the Externalities Costs," Journal of Environmental Planning and Management.

Rinaudo, J. D. \& Loubier, S. (2005). "Méthode des Coûts Evités et Analyse Coûts-Bénéfices des Actions de Dépollution de la Nappe D'Alsace pour Réduire la Pollution Liée aux Mines de Potasse," La Documentation Française ${ }^{\circ} 18$.

Sackhs, I. (1987). 'Ces Temps et Ces Espaces qui S'emboitent, une Terre en Renaissance: Les Semences de Développement Durable,' Le Monde Diplomatique, Savoir $\mathrm{N}^{\circ} 2$.

Schaltegger, S. \& Burrit, R. (2000). "Contemporary Environmental Accounting. Issues, Concepts and Practice," Sheffield, Greenleaf Publishing 2000, ISBN 1-87471934-9, p, 462.

Willinger, M. \& Masson, S. (1996). "Évaluation des Coûts de la Pollution Atmosphérique sur la Santé en Ile de France: Les Difficultés de la Comptabilisation des Dépenses Effectives = Evaluation of Atmospheric Pollution Costs on Health in Ile de France," Dossier Documentaire les Mercredis de l'ADEME, ADEME-BETA. 